\title{
Oksipital kemik yerleşimli langerhans hücreli histiyositozis: Olgu sunumu
}

\author{
Involvement of occipital bone in langerhans cell histiocytosis: A case report \\ Hatice Terzi, Serdal Korkmaz*, Ayşe Akbulut Çiçekli, Ruhiye Cevit, \\ Mehmet Şencan
}

Hematoloji Bilim Dalı (Dr. H. Terzi, Dr. S. Korkmaz, Prof. Dr. M. Şencan), Tıbbi Patoloji Anabilim Dalı (Dr. A. A. Çiçekli), Cumhuriyet Üniversitesi Tıp Fakültesi, TR-58140 Sivas, Patoloji Bölümü (Dr. R. Cevit), Sivas Numune Hastanesi, TR-58040 Sivas

\begin{abstract}
Özet
Langerhans Hücreli Histiyositozis aynı histopatolojiye sahip fakat farklı klinik semptomlara neden olan hastalıklar grubu olarak adlandırılmaktadır. Üç ayrı formu olan hastalığın lokalize formu Eozinofilik granulom olarak isimlendirilmektedir. Eosinofilik granülom, Langerhans Hücreli Histiyositozis grubu içerisinde klinik seyri en az şiddetli ve lokalize form olup en iyi prognoza sahip alt tiptir. Tedavi şeçenekleri arasında, cerrahi eksizyon, kemoterapi, radyoterapi tek başına kullanılabileceği gibi kombine kullanımları da bulunmaktadır. Burada, sağ oksipital bölgede şişlik ve ağrı şikayeti ile kliniğimize başvuran, radyolojik tetkikleri ve histopatolojik incelemesi sonucunda Langerhans Hücreli Histiyositozis (Eosinifilik granülom) tanısı alan genç erişkin bir hasta sunuldu.
\end{abstract}

Anahtar sözcükler: Langerhans hücreli histiyositozis, eozinofilik granülom, soliter kemik lezyonu

\begin{abstract}
Langerhans Cell Histiocytosis is termed as a group of diseases that leads to have same histopathology, but different clinical symptoms. The disease has 3 distinct forms and the localized form is termed as Eosinophilic granuloma . Eosinophilic granuloma is the localized form of which has the least clinical severity and the most favourable subtype in Langerhans Cell Histiocytosis group. The treatment options are available as surgery removal, chemotherapy, and radiotherapy alone or in combinations. In this paper, a young adult patient was represented who referred to our clinic with complaints of swelling and pain on right occipital region, and who diagnosed as Langerhans Cell Histiocytosis (Eosinophilic granuloma) after evaluation of radiologic tests and histopathologic survey.
\end{abstract}

Keywords: Langerhans' Cell Histiocytosis, Eosinophilic granuloma, solitary bone lesion

Geliş tarihi/Received: 18 Nisan 2013; Kabul tarihi/Accepted: 15 Ocak 2014

\section{*İletişim adresi:}

Dr. Serdal Korkmaz, Hematoloji Bilim Dalı, Cumhuriyet Üniversitesi Tıp Fakültesi, TR-58140 Sivas. E-posta: baranserdalkorkmaz@gmail.com

\section{Giriş}

Langerhans Hücreli Histiyositozis (LHH), önceden Histiyositozis X olarak adlandırılan ve yüzey epitelindeki dendritik hücrelerin bir alt tipi olan langerhans hücrelerinin monoklonal ancak malign olmayan proliferasyonu ve farklı organlarda birikimi ile seyreden, etyolojisi bilinmeyen heterojen nadir görülen bir hastalıktır [1-3]. LHH aynı histopatolojiye sahip fakat farklı klinik semptomlara neden olan 3 ayrı forma sahiptir; a. Fulminant formu (Letterer-Siwe hastalığı) b. Kronik rekürren formu (Hand-SchullerChristian hastalığı) c. Lokalize formu [Eozinofilik granulom (EG)] [4-6]. Vücutta 
herhangi bir organı ya da sistemi etkileyebilir, ancak en çok tutulan alanlar kemik (\%80), deri (\%33) ve hipofiz bezidir (\%25). Hastalığın doğal seyri, spontan iyileşebilen lezyonlardan organ birikimleri ile giden ve hayatı tehdit eden sonuçlara kadar geniş bir yelpazede heterojenite göstermekle birlikte kalıcı sekellere de neden olabilir. Hastalık nadir görüldügü ve litaratürde sınırlı sayıda vaka olduğu için bir çok tedavi yöntemi belirsiz ve tartışmalı olarak kalmıştır [7-11]. EG, LHH grubu hastalıkların lokalize formu olup, diğerlerine göre daha iyi prognoza sahiptir. Genellikle çocuklarda görülür ve litik kemik lezyonları ile karakterizedir. Burada, sağ oksipital bölgede şişlik ve ağrı şikayeti ile kliniğimize başvuran ve radyolojik tetkiklerinde litik kemik lezyonu saptanan, histopatolojik incelemesinde Langerhans Hücreli Histiyositozis (Eozinofilik granülom) tanısı alan ve cerrahi eksizyon ile tam remisyon elde edilen genç erişkin bir hasta sunuldu.

\section{Olgu sunumu}

Oksipital bölgede baş ağrısı ve lokalize şişlik şikayetleri olan 20 yaşındaki bayan hastanın fizik muayenesinde oksipital bölgede yumuşak kıvamlı $1 \mathrm{x} 1 \mathrm{~cm}$ genişliğinde kitle saptand1. Direkt kraniografide sağ oksipital bölgede $1 \mathrm{x} 1 \mathrm{~cm}$ çapında osteolitik kemik lezyonu saptandı (Şekil 1). Bu litik lezyondan tanı amaçlı biyopsi alındı. Biyopsi materyalinin parafin bloktan elde edilen kesitler üzerinde, Streptovidin biyotin yöntemi ile Bond Max-Leica cihazı kullanılarak immunhistokimyasal çalışma yapılmıştır. İmmunhistokimyasal olarak CD68 (+), CD1a (+), S-100 fokal (+), Desmin (-) ve HHF35 (-) olarak boyanması sonucunda Langerhans Hücreli Histiyositozis (Eozinofilik Granülom) tanısı konuldu. Kranial Manyetik Rezonans (MRI) görüntülemesinde, sentrum semiovale düzleminde oksipital kemikte sağ tarafta iç-dış tabulada destrüksiyon oluşturan $1 \mathrm{~cm}$ çapında patolojik nodüler sinyal değişikliği izlendi. Sonrasında hastanın oksipital kemikteki lezyonu total olarak eksize edildi. Eksize edilen lezyonun histopatolojik incelenmesi sonucu aynı patolojik tanı elde edildi. Sistemik tutulum olup olmadığını ekarte etmek için çekilen boyun, toraks ve abdomen tomografilerinde patoloji saptanmadı. Kemik iliği aspirasyon ve biyopsisi materyallerinde tutulum olmadığı görüldü. Ek olarak genital sistem, diş ve dişeti, nörolojik, orbita ve işitme muayenelerinde patoloji saptanmadi. Sonuçta lokalize hastalık olarak kabul edilen olgunun histopatolojik incelemesi sonucu cerrahi sınır negatif olduğu için radyoterapi ve/veya kemoterapi tarzı tedavi modaliteleri düşünülmedi. Cerrahi eksizyon ile kür elde edilen hasta 18 aydır takipte olup halen remisyonda seyretmektedir. 


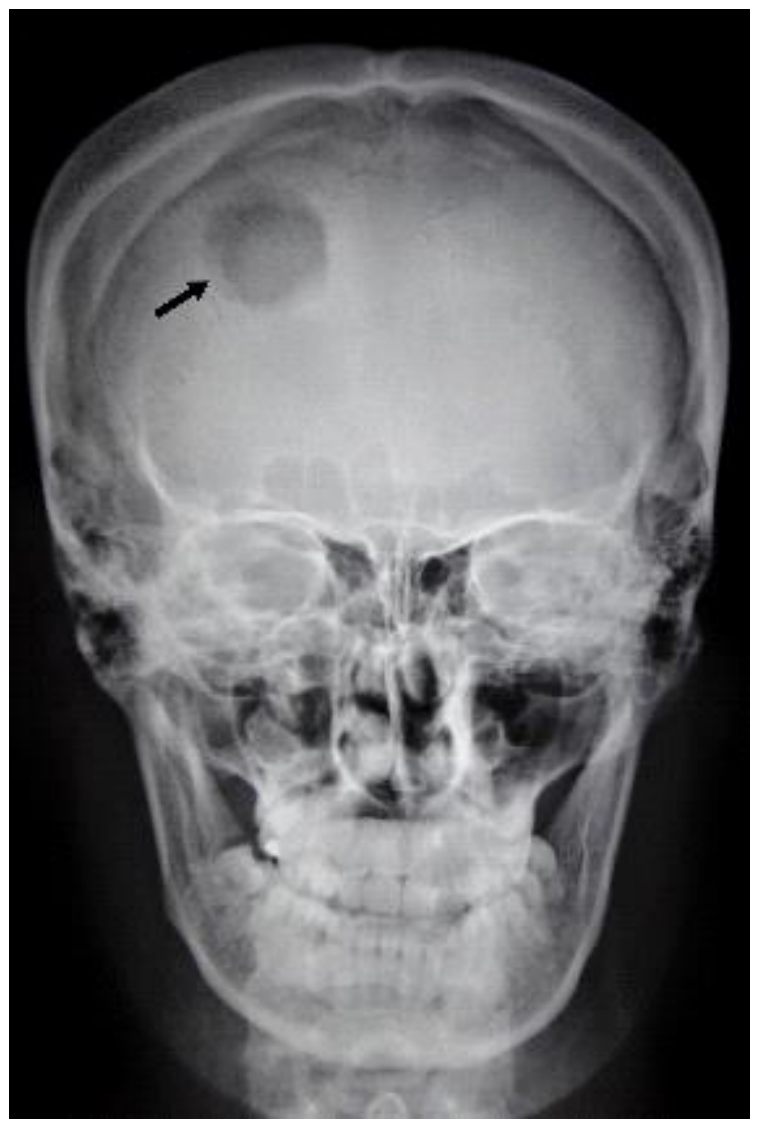

Şekil 1. Sağ oksipital bölgede 1x1 cm çapında osteolitik kemik lezyonu (Direkt kafa grafisi).

\section{Tartışma}

Langerhans hücreleri, kemik iliğindeki prekürsör hücrelerden köken alan mononükleer fagosit sistemin bir komponentidir. Langerhans hücreleri fagositik fonksiyonlarının yanısira $\mathrm{T}$ lenfositlere antijen sunumunda da rol oynar. LHH, nadiren otoimmun bir hastalığın manifestasyonu ya da atipik immunolojik reaksiyonla kendini gösterebilen ve nedeni bilinmeyen non-neoplastik spesifik inflamatuar bir hastalık grubudur. [12]

Hastalık, Eosinofilik granülom (kronik lokal formu), Hand-Schüller-Christian hastalığı (kronik yaygın formu) ve Letterer-Siwe hastalığı (akut yaygın formu) olmak üzere üç ayrı formda incelenmektedir [13]. EG, langerhans hücreli histiositozisin tipik kemik lezyonu ile tanımlanan en yaygın formudur [14]. EG, nispeten nadir görülen bir hastalık olup, tüm tümör benzeri kemik lezyonlarının \%1'inden azını oluşturur [15]. EG, en sık tutulum yeri kafatasıdır [12]. Kafatasında, sıklıkla frontal, paryetal ve temporal kemikte lezyona neden olur [16]. Tek kemik lezyonu olan hastaların yaklaşık yarısı 10 yaşın altındadır ve erişkin hastalarda daha nadir görülmektedir. Hastalar genelde etkilenen bölgede lokalize ağrı (\%44) ve şişlik (\%48) ile başvururlar. Burada sunulan olguda da sağ oksipital bölgede lokalize ağrı ve şişlik mevcuttu.

LHH tanısı, klinik özelikler ve radyolojik tetkiklerle birlikte lezyondan alınan biyopsinin histolojik ve immunfenotipik incelemesi ile konulur. Sistemik tutulum düşünülüyorsa etkilenen organdan da biyopsi örneği alınmalıdır. Esas tanısal özellik karakteristik LHH hücrelerinin morfolojik olarak tanımlanması ise de, lezyondan elde edilen hücrelerin CD1a ve/veya CD207 (Langerin) ile pozitif olarak boyanması kesin tanıyı sağlar [17]. Olgudan elde edilen dokunun morfolojik incelemesine ek olarak immunhistokimyasal çalışma da yapılmış, CD1a ve S-100 ile pozitif boyanma tespit edilmiştir (Şekil 2). 


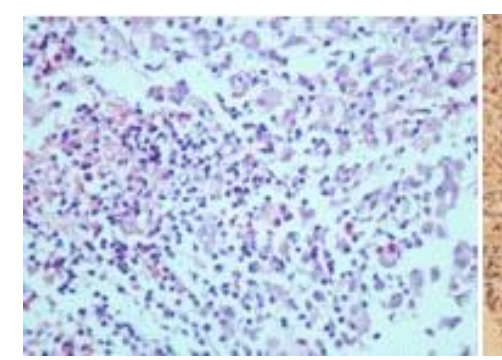

a. $H \& E$

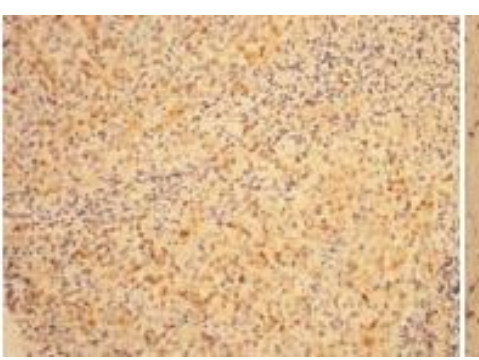

b. $\mathrm{S}-100$

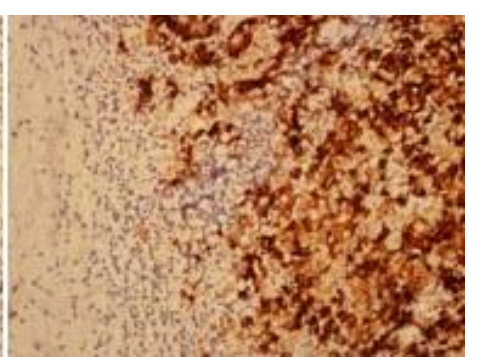

c. CD1a

Şekil 2. LHH (EG) tanısı almış vakanın patoloji preparatları.

a. Zeminde eozinofil ve lenfositler arasında bol langerhans hücreleri (H\&E, x400).

b. S-100 ile sitoplazmik ve nükleer boyanma gösteren langerhans hücreleri (ABP, $\mathbf{x 2 0 0 ) .}$

c. CD1a ile sitoplazmik ve fokal dot şeklinde boyanma gösteren langerhans hücreleri (ABP, x200).

\section{ABP: Avidin Biotin Peroksidaz.}

EG'un radyografisinde zımba ile delinmiş gibi görünen litik kemik lezyonları saptanır, olguda da direkt kafa grafisinde oksipital kemikte litik kemik lezyonu gözlenmiştir. EG radyografik lezyonlar1, osteosarkoma, Ewing sarkom, hemangioma ve dermoid kist gibi malign ya da benign diğer kemik lezyonlarına benzerlik gösterdiğinden ayırıcı tanıda mutlaka düşünülmelidir. Değerlendirmede ilk adım tam bir anamnez almaktır. Sorgulanması gereken spesifik semptomlar ağrı, şişlik, deri döküntü ve kızarıklıkları, otore, irritabilite, ateş, iştah kaybı, diare, kilo kaybı, büyüme geriliği, polidipsi, poliüri, aktivite seviyesinde değişiklikler, dispne, davranışsal ve nörolojik değişikliklerdir. Olguda, baş ağrısı ve lokalize şişlik haricinde bulgu yoktu. Değerlendirmenin ikinci basamağı laboratuvar ve görüntülemedir. Bunlar içerinde tam kan sayımı, karaciğer fonksiyon testleri, toraks ve kemik grafi tetkikleri ilk başta yer alır. Poliuri ve polidipsi öyküsü olan hastalarda sabah idrarının dansite ve osmolarite için değerlendirilmesi, kan elektrolit tayini ve mümkünse su kısıtlama testi diabetes insipitusu ekarte etmek için yapılmalıdır. Bisitopeni, pansitopeni ya da persistan açıklanamayan tek seride sitopeni durumlarında LHH dışındaki nedenleri ekarte edebilmek için, kemik iliği aspirasyonu ve biyopsisi yapılmalıdır. Karaciğer fonksiyon bozukluğu saptanması abdominal ultrasonografi yapılmasını ve bir hepatolog ile konsültasyonu gerektirir. Karaciğer MRI belirgin karaciğer disfonksiyonu olan (karaciğer enzimleri normalin 5 katı yükseklikte ya da bilirubin normalden 5 kat daha fazla olan) hastalarda tercih edilmektedir. Anormal toraks grafisi olması ya da akciğer tutulumunu düşündüren semptom varlığında yüksek rezolüsyonlu bilgisayarlı tomografi (HRCT) ve akciğer fonksiyon testlerinin yapılması gerekmektedir. Bronkoalveolar lavaj, enfeksiyon gibi diğer bulguları ekarte etmekte kullanılabilir ve HRCT yerine tercih edilebilir. Son olarak da eğer akciğer tutulum şüphesi halen devam ediyorsa akciğer biyopsisi gerekebilir. Vertebral lezyonlarda spinal kord basısını ve intrakranial kitleleri göstermesi açısından MRI gerekebilmektedir. Olguyu klinik, laboratuar ve görüntüleme tetkikleri ile sistemik olarak değerlendirdiğimizde herhangi bir organ tutulumu olmadığ 1 ve son olarak da histopatolojik inceleme ile LHH (EG) varlığ1 saptanmıştır.

LHH tanısı kesinleştiği zaman her bir birey için tedavi yaklaşımı bireyselleştirilmelidir. Histiositozların tedavisinde, cerrahi eksizyon, radyoterapi, kemoterapi ve lokal steroid tedavisi tek başına ya da kombine olarak kullanılmaktadır. Soliter kemik lezyonlarının tedavisinde cerrahi eksizyon tek başına yeterli olmaktadır. Ayrıca, literatürde spontan regresyon olduğunu gösteren izole vaka takdimleri de mevcuttur [18-20]. Burada sunulan olguda da, oksipital kemikte lokalize litik lezyon olduğu için total cerrahi eksizyon kararı alınmıştır ve eksizyon sonrası patolojik incelemede cerrahi sınırlar negatif olduğundan ek tedavi yaklaşımı düşünülmemiştir. 
Sonuç olarak, LHH nadir görülen bir hastalıktır. LHH'un bir alt tipi olan EG genelde pediatrik ve adolesan yaş grubunun bir hastalığı olmakla birlikte genç erişkinlerde de görülebileceği için özellikle kemikte soliter osteolitik lezyon saptandığında ayırıcı tanıda mutlaka düşünülmelidir.

\section{Kaynaklar}

1. Leatherwood DL, Heitkamp DE, Emerson RE. Best cases from the AFIP: Pulmonary Langerhans cell histiocytosis. Radiographics 2007; 27: 265-8.

2. Minkov M, Grois N, Braier J, Rosso D, Aricò M, Broadbent V, Gadner H, Ladisch S; Histiocyte Society. Immunosuppressive treatment for chemotherapyresistant multisystem Langerhans cell histiocytosis. Med Pediatr Oncol 2003; 40: 253-6.

3. Madrigal-Martínez-Pereda C, Guerrero-Rodríguez V, Guisado-Moya B, MenizGarcía C. Langerhans cell histiocytosis: Literature review and descriptive analysis of oral manifestations. Med Oral Patol Oral Cir Bucal 2009; 14: 222-8.

4. Scolozzi P, Lombardi T, Monnier P, Jaques B. Multisystem Langerhans' cell histiocytosis (Hand-Schüller-Christian disease) in an adult: A case report and review of the literature. Eur Arch Otorhinolaryngol 2004; 261: 326-30.

5. Meyer JS, De Camargo B. The role of radiology in the diagnosis and follow-up of Langerhans cell histiocytosis. Hematol Oncol Clin North Am 1998; 12: 307-26.

6. Sezer ÖC, Alpar S, Bakırcı T, Demirağ F, Kurt B. Diabetes insipidus ile Birlikte Olan Pulmoner Histiositozis X Olgusu. Türkiye Klinikleri Arch Lung 2001; 2: 156-8.

7. Gadner H, Heitger A, Grois N, Gatterer-Menz I, Ladisch S. Treatment strategy for disseminated Langerhans cell histiocytosis. DAL HX-83 Study Group. Med Pediatr Oncol 1994; 23: 72-80.

8. Gadner H, Grois N, Arico M, Broadbent V, Ceci A, Jakobson A, Komp D, Michaelis J, Nicholson S, Pötschger U, Pritchard J, Ladisch S; Histiocyte Society. A randomized trial of treatment for multisystem Langerhans' cell histiocytosis. J Pediatr 2001; 138: 728-34.

9. Gadner H, Grois N, Pötschger U, Minkov M, Aricò M, Braier J, Broadbent V, Donadieu J, Henter JI, McCarter R, Ladisch S; Histiocyte Society. Improved outcome in multisystem Langerhans cell histiocytosis is associated with therapy intensification. Blood 2007; 111: 2556-62.

10. Minkov M, Grois N, Heitger A, Pötschger U, Westermeier T, Gadner H. Treatment of multisystem Langerhans cell histiocytosis. Results of the DAL-HX 83 and DAL-HX 90 studies. DAL-HX Study Group. Klin Padiatr 2000; 212: 13944.

11. A multicentre retrospective survey of Langerhans' cell histiocytosis: 348 cases observed between 1983 and 1993. The French Langerhans' Cell Histiocytosis Study Group. Arch Dis Child 1996; 75: 17-24.

12. Kahilogullari G, Tuna H, Kuzu I, Ünlü A. Orbital Eosinophilic Granuloma in a Child: A Case Report. Turkish Neurosurgery 2013; 23: 575-7.

13. Kilpatrick SE, Wenger DE, Gilchrist GS, Shives TC, Wollan PC, Unni KK. Langerhans' cell histiocytosis (histiocytosis X) of bone. A clinicopathologic analysis of 263 pediatric and adult cases. Cancer 1995; 76: 2471-84.

14. Aydın MA, Baykul T, Nasir S, Altuntaş SH, Türkaslan SS, Fındık Y. Misdiagnosed widespread eosinophilic granuloma of the mandible. J Craniofac Surg 2012; 23: e361-4.

15. Erdem H, Kadıŏlu N, Uzunlar AK, Yücel I, Oktay M, Beşir FH. Langerhans Cell Histiocytosis Mimicking Osteomyelitis in an Infant. APSP J Case Rep 2013; 4: 27.

16. Bozdemir K, Tarlak B, Cakar H, Doblan A, Kutluhan A, Dilek I, Adiyaman Süngü N. Langerhans cell histiocytosis in bilateral mastoid cavity. Case Rep Otolaryngol 2013; 2013: 957926. 
17. Donadieu J, Chalard F, Jeziorski E. Medical management of langerhans cell histiocytosis from diagnosis to treatment. Expert Opin Pharmacother 2012; 13: 1309-22.

18. Martinez-Lage JF, Poza M, Cartagena J, Vicente JP, Biec F, de las Heras M. Solitary eosinophilic granuloma of the pediatric skull and spine. The role of surgery. Childs Nerv Syst 1991; 7: 448-51.

19. Rawlings CE 3rd, Wilkins RH. Solitary eosinophilic granuloma of the skull. Neurosurgery 1984; 15: 155-61.

20. Oliveira M, Steinbok P, Wu J, Heran N, Cochrane D. Spontaneous resolution of calvarial eosinophilic granuloma in children. Pediatr Neurosurg 2003; 38: $247-$ 52. 